\title{
COOPERATIVE TYPE NUMBERED HEADS TOGETHER EFFECT ON STUDENT'S ACHIEVEMENT IN EXPANSION TOPIC
}

\author{
Lucius Marbun dan Motlan \\ Jurusan Fisika Universitas Negeri Medan
}

\begin{abstract}
This research was aimed to know 1) Student's achievement in physics by using numbered heads together (NHT). 2) Student's achievement in physics by using conventional learning model. 3) The effect of numbered heads together (NHT) on student's achievement especially on expansion topic. The population was nine classes student grade VII in SMP N 1 Tebing Tinggi. The sample was two classes obtained by cluster random sampling. The sample was $\mathrm{VII}_{5}$ by using numbered heads together (NHT) and $\mathrm{VII}_{4}$ by using conventional learning model. Instrument has 20 questions and tested validated. The mean of pre-test in $\mathrm{VII}_{5}$ was 38.15 and in $\mathrm{VII}_{4}$ was 38.52. After that learning model applied, and then done the post-test. The mean of post-test in $\mathrm{VII}_{5}$ was 78.15 and in $\mathrm{VII}_{4}$ was 73.52 . In hypothesis testing obtained $t_{\text {count }}>t_{\text {table }}$ at significant level 0.05 . So, can be concluded student's achievement of $\mathrm{VII}_{5}$ better than $\mathrm{VII}_{4}$.
\end{abstract}

Keywords: Numbered Heads Together, Student's Achievement

\section{INTRODUCTION}

Education is very important for all the people. Without the education a person will be difficult adapting to the environment and can not take the maximal function in society. According to Trianto (2009) said that "education that support the construction in the future is the education that can to develop the student potential, so the student able to face and solve their problem in daily life. Education should be touch the inner potential and competence of student."

Physics is the part of natural science has many connected to the phenomena in daily life, thus the concepts is not only theory but also can proved by discovery. Physics education emphases to "understand" and "do" thus can to help the student to mastery the physics concept and then effecting to student's achievement.

The quality of education in Indonesia is very low and concern. Its can be shown in the data of UNESCO year 2012, Indonesia has the rating in 64 from 120 nations. In the last year, Indonesia has the rating 69 from 127 nations (Santoso, October $20^{\text {th }} 2012$ ).

The low of education quality in Indonesia can be seen in the low of student's achievement in some of lesson subject. Physics is one of the subject lesson that low student achievement. This fact is suit when the author done observation in State Junior High School 1 Tebing Tinggi, the author does interview to physics teacher (Binsar Hamoloan, S.Pd), and he said that the student achievement in physics subject is low. The average of student achievement in semester I class VII academic year 2012/2013 is 60.23, whereas the minimal standard is 75 . That's mean the average of student achievement is lower than minimal standard.

When the author do the survey to 27 students by answering the 
questionnaire, gotten the data that 17 students of them not like to learn physics, 7 students said that physics is normally and then only 3 students like to learn physics. In the teaching and learning process in class student answer the questionnaire that 20 students of them like to discuss or making group in teaching process, 7 students answer using props, and no one student answer a lot of work on the problems.

So, base on the problem above there are many kind of model can be applied to improve the student's achievement and make them become active in teaching and learning process. Perhaps the way to improve the student proclivity and motivation to learn physics is to change the teaching and learning process become interest. The model that wants to apply is the cooperative learning model type numbered head together. Stahl in Isjoni (2009) argues that "cooperative learning can to improve the learning achievement of student and make them to be mutual assistance in social behaviour".

\section{RESEARCH METHOD}

This research has been done in RSBI State Junior High School 1 Tebing Tinggi grade VII academic year 2012/2013.

The procedures of this reseacrh was: Determine class sample from population. Get 2 classes, one as the experiment class and another as the control class, both classes consist of 27 students. Pre-test for both classes in multiple choice question, to know initial ability of student. Student in experiment class use cooperative learning model type numbered heads together (NHT) and in control class will be done teach with conventional learning model. Given the post-test for both classes to know student achievment after study the topic with the different learning model.

The instrument in this research has 20 questions in multiple choice forms with 4 options. This instrument corrected by 3 validates they are physics lecture in State University of Medan.

\section{Technique of Data Analysis Normality test}

To determine whether normal distribution of data relating to the use of data analysis Lilliefors test. According to Sudjana (2002), the steps to test normality is:

a. $Z i=\frac{X_{i}-\bar{X}}{s}$

Where: $X_{i}=$ Respondent $X_{1}$, $X_{2}, \ldots \ldots, X_{n}$

$\bar{X}=$ Mean

$\mathrm{S}=$ Deviation standard

b. Calculating the probability $\mathrm{F}(\mathrm{Zi})=\mathrm{P}(\mathrm{Z}<\mathrm{Zi})$

c. Calculating the proportion $Z_{1}$, $Z_{2}, Z_{3}, \ldots \ldots \ldots, Z_{n}$ small than or equal to $\mathrm{Zi}$. If the proportion we symbolic with $\mathrm{S}(\mathrm{Zi})$ so:

$S(Z i)=\frac{\text { Total } Z_{1}, \ldots Z_{n}, \text { while } \leq Z_{i}}{N}$

d. Calculate deviation $\mathrm{F}$ $\left.Z_{i}\right)-S\left(Z_{i}\right)$ while we get the absolute value.

e. Taking the absolute value of the difference between the greatest and called Lo, and then the significant degree $\alpha=0.05$ and to calculate Lo with compare with the critical value of $\mathrm{L}$ is taken from the list of critical value to test Lilliefors.

Lo $<\mathrm{L}_{\text {tabel }}$ so sample normal distributed 
Lo $>\mathrm{L}_{\text {tabel }}$ so sample not normal distributed

\section{Homogeneity Test}

In this part will be do test of variants similarity for two normal population with standard deviation is $\sigma_{1}$ and $\sigma_{2}$. Will be test with test two parts:

$\mathrm{H}_{0}=\sigma_{1}{ }^{2}=\sigma_{2}{ }^{2}$

$\mathrm{H}_{\mathrm{a}}=\sigma_{1}{ }^{2} \neq \sigma_{2}{ }^{2}$

To test the homogeneity of sample variants, test of variants homogeneity using the $\mathrm{F}$ test with the formula according to Sudjana (2002) is:

$$
F=\frac{S_{1}^{2}}{S_{2}^{2}}
$$

Where: $S_{1}^{2}=$ Variants from experiment class $S_{2}^{2}=$ Variants from control class

With the criteria:

$$
\text { a. If } F_{h}<F_{\frac{1}{2} \alpha\left(v_{1}-v_{2}\right)} \text { so } S_{1}{ }^{2}=S_{2}{ }^{2}
$$
or both of population have the same variance

b. If $F_{h} \geq F_{\frac{1}{2} \alpha\left(v_{1}-v_{2}\right)}$ so $S_{1}^{2}>S_{2}^{2}$ or both of population have not same variance

$F_{\frac{1}{2} \alpha\left(v_{1}-v_{2}\right)}$ gotten from distribution of F with the probability is $\frac{1}{2} \alpha$, while $\mathrm{dk}$ counter is $\left(n_{1}-1\right)$ and $\mathrm{dk}$ denominator $=\left(n_{2}-1\right)$ with the reality level $\alpha=$ 0.10 .

\section{Hypothesis Test}

Hypothesis test calculate with 2 kinds are:

\section{a. Pre-test ability Test (two tail test)}

$\mathrm{T}$ test is used to determine the similar ability of student in both samples
The form of hypothesis test is:

$\mathrm{H}_{0}: \mu_{1}=\mu_{2}$ : Experiment class and control class have same similar ability

$\mathrm{H}_{\mathrm{a}}: \mu_{1} \neq \mu_{2}:$ Experiment class and control class have not same similar ability

Hypothesis use different test with formula:

$$
t=\frac{\overline{X_{1}}-\overline{X_{2}}}{S \sqrt{\frac{1}{n_{2}}+\frac{1}{n_{2}}}}
$$

(Sudjana, 2002)

With $\mathrm{S}$ is combination of deviation standard can calculate with the formula according to Sudjana (2002):

$$
S^{2}=\frac{\left(n_{1}-1\right) S_{1}^{2}+\left(n_{2}-1\right) S_{2}^{2}}{n_{1}+n_{2}-2}
$$

Where:

$\overline{X_{1}}=$ The mean score of student's achievement in the experiment class.

$\overline{X_{2}}=$ The mean score of student's achievement in the control class

$n_{1}=$ Total student in experiment class.

$n_{2}=$ Total student in control class .

$S^{2}=$ Variants two of class

$\mathrm{t}=$ Value of $\mathrm{t}$

With the criteria is:

$\mathrm{H}_{0}$ accepted if $-t_{1-1 / 2^{\alpha}}<t<t_{1-1 / 2^{\alpha}}$ where $t_{1-1 / 2^{\alpha}}$ we get from $\mathrm{t}$ list with $\mathrm{dk}$ $=\mathrm{n}_{1}+\mathrm{n}_{2}-2$ and probability $\left(1-\frac{1}{2} \alpha\right)$. To another value of $\mathrm{t} \mathrm{H}_{\mathrm{O}}$ not accept.

Value of $t_{\text {count }}$ compare with $t-$ table get from $t$ table list to $\alpha=0.05$. If $-t_{1-1 / 2^{\alpha}}<t<t_{1-1 / 2^{\alpha}}$ on the level $\alpha=$ 0.05 and independent degree $\mathrm{dk}=$ $\mathrm{n}_{1}+\mathrm{n}_{2}-2$, so have the same initial ability of student.

Ha accept if $t_{\text {count }}>t_{\text {table }}\left(t_{\text {table }}\right.$ get from distribution $\mathrm{t}$ list for $\alpha=0.05)$, it is 
mean have not same initial ability of student.

If $S_{1} \neq S_{2}$, so, $t$ test formula will be use is:

$t^{\prime}=\frac{\bar{X}_{1}-\bar{X}_{2}}{\sqrt{\left(S_{1}^{2} / n_{1}\right)+\left(S_{2}^{2} / n_{2}\right)}}$

With test criteria: accept $\mathrm{H}_{0}$ if:

$-\frac{w_{1} t_{1}+w_{2} t_{2}}{w_{1}+w_{2}}<t^{\prime}<\frac{w_{1} t_{1}+w_{2} t_{2}}{w_{1}+w_{2}}$

With $w_{1}=S_{1}^{2} / n_{1} ; w_{2}=S_{2}^{2} / n_{2}$

$t_{1}=t_{(1-1 / 2 \alpha),\left(n_{1}-1\right)} ; t_{2}=t_{(1-1 / 2 \alpha),\left(n_{2}-1\right)}$

\section{b. Post-test ability test (One Tail Test)}

The form of hypothesis test is:

$\mathrm{H}_{0}: \mu_{1} \leq \mu_{2}=$ there is not the effect

of cooperative learning model

type numbered Heads

Together (NHT) on student's achievement

$\mathrm{H}_{\mathrm{a}}: \mu_{1}>\mu_{2}=$ has the effect of

cooperative learning model

type Numbered

Heads Together (NHT) on student achievement

Hypothesis in the research use $t$ test with the formula is:

\section{RESEARCH RESULT AND DISCUSSION}

The results of research conducted to

Table 1 Pre test score in Experiment and Control class

\begin{tabular}{|c|c|c|c|c|c|c|c|c|}
\hline \multirow[t]{2}{*}{ No } & \multicolumn{4}{|c|}{ Experiment Class } & \multicolumn{4}{|c|}{ Control Class } \\
\hline & Score & $\mathbf{F}_{1}$ & $\bar{X}$ & $\mathbf{S}$ & Score & $\mathbf{F}_{1}$ & $\overline{\bar{X}}$ & $\mathbf{S}$ \\
\hline 3 & 25 & 1 & \multirow{6}{*}{38.15} & \multirow{6}{*}{7.36} & 25 & 1 & \multirow{6}{*}{38.52} & \multirow{6}{*}{5.69} \\
\hline 4 & 30 & 7 & & & 30 & 2 & & \\
\hline 5 & 35 & 5 & & & 35 & 9 & & \\
\hline 6 & 40 & 5 & & & 40 & 8 & & \\
\hline 7 & 45 & 6 & & & 45 & 6 & & \\
\hline 8 & 50 & 3 & & & 50 & 1 & & \\
\hline & Total & 27 & & & Total & 27 & & \\
\hline
\end{tabular}

$$
t=\frac{\overline{X_{1}}-\overline{X_{2}}}{S \sqrt{\frac{1}{n_{1}}+\frac{1}{n_{2}}}}
$$

With:

$$
S^{2}=\frac{\left(n_{1}-1\right) S_{1}^{2}+\left(n_{2}-1\right) S_{2}^{2}}{n_{1}+n_{2}-2}
$$

With test criteria is:

$\mathrm{H}_{\mathrm{a}}$ accept if $\mathrm{t}_{\text {count }}>\mathrm{t}_{(1-\alpha)}$ where $\mathrm{t}_{(1-}$ $\alpha$ ) get from distribution table $\mathrm{t}$ with independent degree $(\mathrm{dk})=\mathrm{n}_{1}+\mathrm{n}_{2}-2$ and the probability $(1-\alpha)$ with $\alpha=$ 0.05 for another value of $\mathrm{t} \mathrm{Ha}$ not accept, so cooperative learning model type Numbered Heads Together (NHT) have effect in student's achievement.

If $S_{1} \neq S_{2}$, so the formula t tests use:

$$
t^{\prime}=\frac{\bar{X}_{1}-\bar{X}_{2}}{\sqrt{\left(S_{1}^{2} / n_{1}\right)+\left(S_{2}^{2} / n_{2}\right)}}
$$

Test criteria not accept is: not accept $\mathrm{H}_{0}$ if:

$t^{\prime} \geq \frac{w_{1} t_{1}+w_{2} t_{2}}{w_{1}+w_{2}}$

With $w_{1}=S_{1}^{2} / n_{1} ; w_{2}=S_{2}^{2} / n_{2}$

$t_{1}=t_{(1-\alpha),\left(n_{1}-1\right)} ; t_{2}=t_{(1-\alpha),\left(n_{2}-1\right)}$

know students learning achievement before the two of samples applied different treatments. 
To know clearly the comparison of pre test score in Experiment and Control Class can see in diagram below:

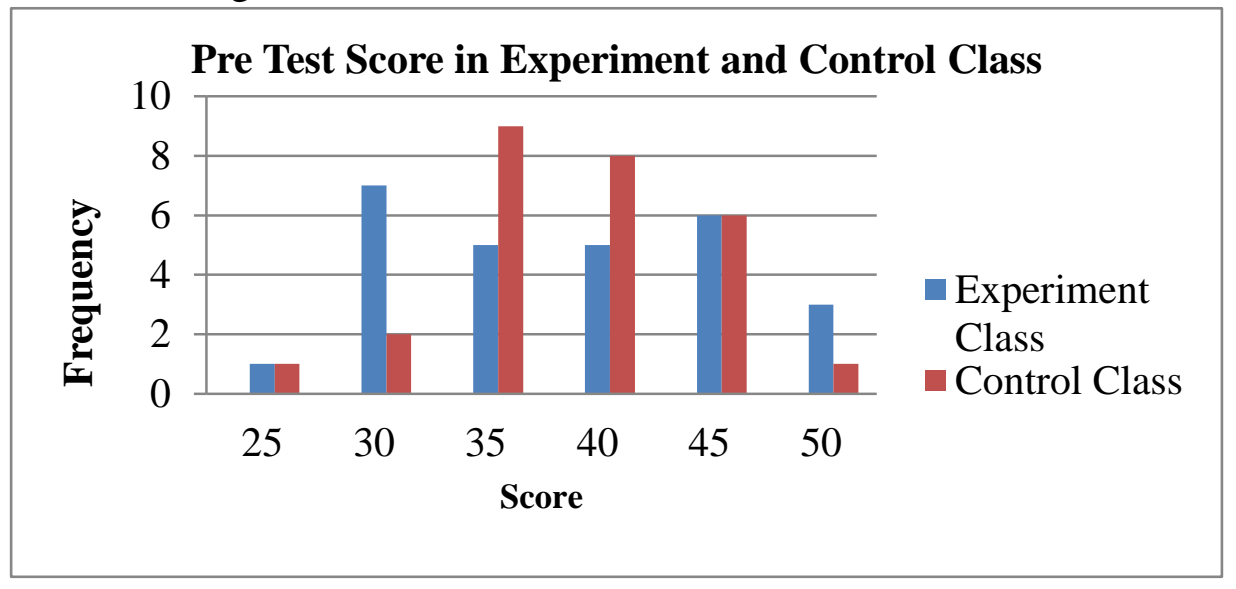

Figure 1 Column Diagram Pre test score data in Experiment and Control Class

\section{Normality Test of Pre-Test Data}

The result of normality test in

experiment and control class

described below

Table 2 Normality test of pre-test data in Experiment and Control class

\begin{tabular}{|c|c|c|c|}
\hline \multirow{2}{*}{ Class } & \multicolumn{2}{|c|}{ Pre-Test Data } & \multirow{2}{*}{ Conclusion } \\
\cline { 2 - 3 } & Lcount & Ltable & \\
\hline Experiment & 0.1606 & 0.1682 & Normal \\
\hline Control & 0.1601 & 0.1682 & Normal
\end{tabular}

Based on table 2 got $\mathbf{L}$ count $<$ Ltable can be concluded of pre-test data from both classes are normal distribution.

Homogeneity test of Pre-test The result can described below:

Table 3 Homogeneity Test of Pre-Test Data

\begin{tabular}{|c|c|c|c|c|}
\hline Data & Variant & F $_{\text {count }}$ & F $_{\text {table }}$ & Conclusion \\
\hline Experiment & 54.17 & 1.67 & 1.93 & Homogeny \\
\hline Control & 32.38 & & & \\
& & & & \\
\hline
\end{tabular}

In table $3, \mathrm{~F}_{\text {count }}<\mathrm{F}_{\text {table }}$ it's mean that the sample in this research is homogeny.

$\mathrm{T}$ test two parties are used to determine the similarity of student

Hypothesis Test of Pre-test Data ability at the first both groups of samples. Can describe below

Table 4 Hypothesis Test of Pre-Test Data

\begin{tabular}{|c|c|c|c|c|}
\hline Data & Mean & $\mathbf{t}_{\text {count }}$ & ttable & Conclusion \\
\hline Experiment Class & 38.15 & -0.207 & 2.012 & $\begin{array}{c}\text { Initial student } \\
\text { ability is same }\end{array}$ \\
\cline { 1 - 2 } Control Class & 38.52 & & &
\end{tabular}


Post Test Score of Students in

After the both samples applied Experiment and Control Class different treatment, post-test done to take data of student's achievement.

Table 5 Post-Test Data in Experiment Class and Control Class

\begin{tabular}{|c|c|c|c|c|c|c|c|}
\hline \multicolumn{4}{|c|}{ Experiment Class } & \multicolumn{4}{|c|}{ Control Class } \\
\hline Score & Frequency & Mean & $\begin{array}{c}\text { Deviation } \\
\text { standard }\end{array}$ & Score & Frequency & Mean & $\begin{array}{c}\text { Deviation } \\
\text { standard }\end{array}$ \\
\hline 60 & 2 & \multirow{8}{*}{78.15} & \multirow{8}{*}{7.09} & 55 & 1 & \multirow{8}{*}{73.52} & \multirow{8}{*}{9.39} \\
\hline 65 & 0 & & & 60 & 4 & & \\
\hline 70 & 0 & & & 65 & 4 & & \\
\hline 75 & 11 & & & 70 & 3 & & \\
\hline 80 & 7 & & & 75 & 2 & & \\
\hline 85 & 5 & & & 80 & 8 & & \\
\hline 90 & 2 & & & 85 & 5 & & \\
\hline \multicolumn{2}{|c|}{ Total $=27$} & & & Total & 27 & & \\
\hline
\end{tabular}

To saw the post-test result with specified shown in diagram below

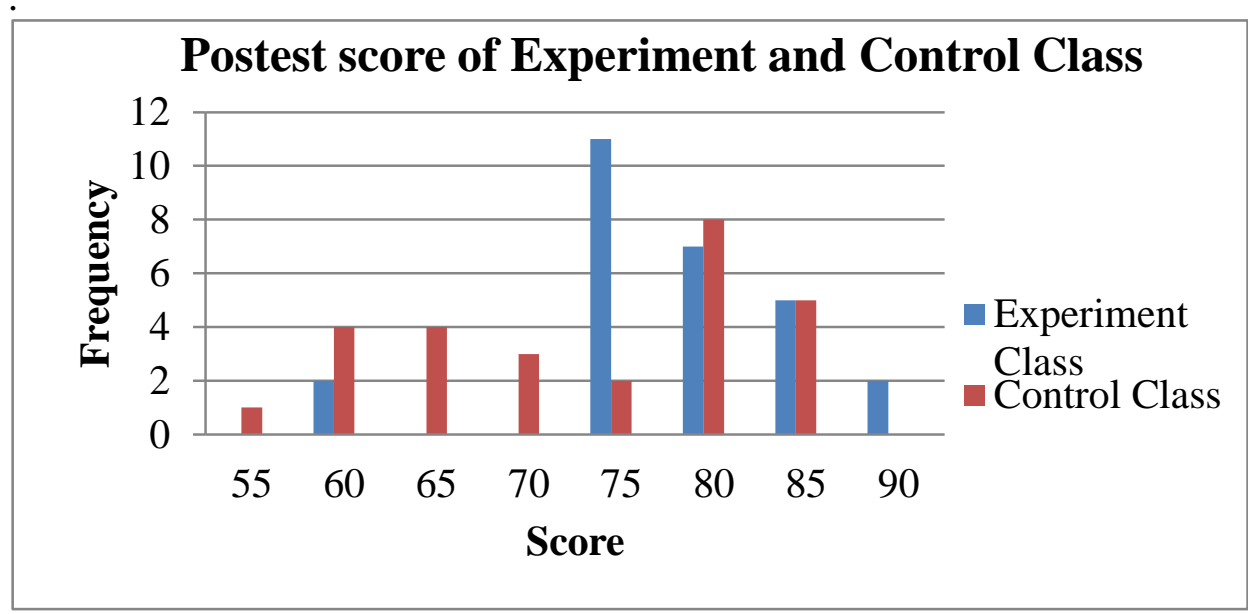

Figure 2 Column Diagram Post test score data in Experiment and Control Class

Normality Test of Post-Test Data

The result of normality test in experiment and control class described below:

Table 6 Normality Test of Post-Test Data in Experiment and Control Class

\begin{tabular}{|c|c|c|c|}
\hline \multirow{2}{*}{ Class } & \multicolumn{2}{|c|}{ Post-Test Data } & \multirow{2}{*}{ Conclusion } \\
\cline { 2 - 3 } & Lcount & Ltable & \\
\hline Experiment & 0.1515 & 0.1682 & Normal \\
\hline Control & 0.1411 & 0.1682 & Normal \\
& & & \\
\hline
\end{tabular}

Homogeneity test of Post-Test

Table 7 Homogeneity Test of Post Test Data

\begin{tabular}{|l|l|l|l|l|}
\hline Class & Variant & $\mathbf{F}_{\text {count }}$ & $\mathbf{F}_{\text {table }}$ & Conclusion \\
\hline
\end{tabular}




\begin{tabular}{|c|l|l|l|l|}
\hline Experiment & 50.27 & 1.75 & 1.93 & Homogeny \\
\cline { 1 - 2 } Control & 88.17 & & & \\
\hline
\end{tabular}

\section{Hypothesis Test of Post-test}

Hypothesis testing is a requirement that is used to determine whether the
Ho in the research accepted or rejected. The data used to know the different of student ability after have treatment.

Table 8 Hypothesis Test of Pos-Test Data

\begin{tabular}{|c|c|c|c|l|}
\hline Class & Mean & $\mathbf{T}_{\text {count }}$ & $\mathbf{t}_{\text {table }}$ & \multicolumn{1}{|c|}{ Conclusion } \\
\hline Experiment & 78.15 & 2.03 & 1.676 & $\begin{array}{l}\text { Has the effect of Numbered Heads } \\
\text { Together (NHT) on student's achievement }\end{array}$ \\
\hline Control & 73.52 & & & \\
\hline
\end{tabular}

\section{Discussion}

The increasing of student's achievement in experiment class because the teaching and learning process using cooperative learning model type numbered heads together (NHT) given the advantage to student that has low ability. Because the student has high ability can to help their friend and the student has low ability get the information from their friend, this situation occurrence when the student work and learn in group.

Cooperative leaning model type numbered heads together has four steps, that is (1) Numbering, (2) Questioning, (3) Heads Together, and (4) Answering. NHT is heterogeneous groupings of students are used. There is one high achieving student, one low achieving student and three average achieving students on a learning team. According to Bawm (2007) said that in NHT model student sit with their small team while the teacher conducts the lesson. The teacher gives a question to the class and students confer with their team. Student teams make sure that all students in their group understand the answer.

In this research, the task given by teacher ask student to work each other and responsible to their group. The presence of individual responsibility imposed to each member, oblige the student to help their friend, improve their group ability, this process occurrence when guide the student work and learn in group.

In control class taught by conventional learning model, the student much most to listen the explanation of teacher and do the task if teacher give problem. And according to Sanjaya (2008) argues that conventional learning model is teacher centred.

In hypothesis test showed that the different increasing of student achievement in experiment and control class. The student's achievement is better in experiment class. So, can be concluded have the effect of cooperative learning model type Numbered Heads Together (NHT) student's achievement on sub topic expansion in Grade VII SMP N 1 Tebing Tinggi academic year 2012/2013.

The cooperative learning model type numbered heads together has been researched by M Noer, (2009), Ratnamalawati (2012), and Rika \& Titin (2013). And the result of this research is suitable with their research result, where in their result gotten student's achievement taught by 
numbered heads together (NHT) better than conventional learning model.

Although the Cooperative Learning Model type Numbered Heads Together (NHT) can to improve learning achievement, but during in teaching and learning process the Numbered Heads Together (NHT) has the disadvantage, that is the student not ready and afraid to present they discussion result when the teacher call their number, so the student not effective to present it. So, for the next author who want to do research using Numbered Heads Together (NHT) learning model, for the first her/him motivate their student to discuss each other, and giving the reward or add value for the student that active when present their discussion result. And then appreciate the answer and discuss result of student with say thank to student to develop their confidence.

\section{CONCLUSION}

AND

\section{SUGGESTION}

Based on result research and data collection, can be concluded that: Student's achievement in experiment class after taught by using cooperative learning model type numbered heads together (NHT) was increase and has the mean score 78.15. Student's achievement in control class after taught by using conventional learning model also increase and has the mean score 73.52. Student's achievement in experiment class was greater than student's achievement in control class. So, cooperative learning model type numbered heads together (NHT) has the effect on student's achievement.

According to the data of student's achievement and the experience of author when applying the cooperative learning model type numbered heads together (NHT) in class, so the author gives suggestion for the next researcher who wants to do research using cooperative model type numbered heads together (NHT), its better teacher give motivate to student to develop their confidence that will present their discuss result, because not all student ready to present it and allocate the time for each step because Numbered Heads Together require much time especially when student present their discuss result. And teacher can use the numbered heads together (NHT) to increase student's achievement.

\section{REFERENCES}

Arends. R. I. 2009. Learning to

Teach. New York: McGraw-

Hill

Arikunto, S. 2009. Dasar-Dasar

Evaluasi Pendidikan. Jakarta: Bumi Aksara

Arsyah. A. 2008. Media

Pembelajaran. Jakarta: Raja Grafindo

Bawn. S. 2007. The Effects of

Cooperative Learning on Learning and Engagement.

America: The Evergreen State College

Dalimunte. Y. K. 2011. Pengaruh

Strategi Genius Learning
Terhadap Hasil Belajar
Siswa pada Materi Pokok
Listrik Dinamis di Kelas X
Unggulan 1 Semester II MAN
1 Medan. Medan: FMIPA
UNIMED

Daroji \& Haryati. 2010. The

Essencials of Physics. Solo: Tiga Serangkai

Dymiati dan Mudjiono. 2002. Belajar 
dan Pembelajaran. Jakarta: Rineka Pers

Faridah. 2012. Pembelajaran Berdasarkan Pendekatan Kontekstual. Sulawesi Selatan: Widyaiswari LPMP

Isjoni. 2009. Pembelajaran Koperatif.

Yogyakarta. Pustaka Pelajar

Lia. A. 2010. Cooperative Learning.

Jakarta: Grasindo

Macpherson. A. 2007. Cooperative

Learning Group Activities for College Courses.

America: Kwantlen University College

Manullang. M. 2012. Pengaruh

Model Pembelajaran Koperatif Tipe Numbered Head Together (NHT) Terhadap Hasil Belajar Siswa pada Materi Listrik Statis di Kelas IX Semester I SMP Swasta GKPI. Padang Bulan Medan. T.A 2012/2013. Medan: FMIPA UNIMED

Marjoribanks. K. 1991. The

Fundation of Student Learning.

Australia: Pergamon Pers

Monnet. B. J. 2006. Classification of

Learning Activities -Manual. Luxembourg: European Communities

Noer, M. Lily Suryani \& Zuhelmi.

2009. Keterampilan Sosial Siswa dalam

Pembelajaran Fisika Melalui Penerapan Model Kooperatif NHT dan

TSOS di Kelas X SMA Negeri 12 Pekanbaru. Jurnal Geliga Sains
Prasodjo, B. 2009. Physics for Junior

High School. Jakarta: Yudistira

Ratnamalawati. 2012. Analisis

Kemampuan Prasyarat

Matematika dan Hasil

Belajar Fisika Pada

Pembelajaran Menggunakan ModelKoopperatif Tipe

Numbered Heads Together (NHT). Jurnal Online Pendidikan Fisika

Sanjaya, W. 2008. Strategi

Pembelajaran. Jakarta. Prenada Pers

Santoso. M. 2013. Indeks Pendidikan

Indonesia .

http://cetak.kompas.com/read/2 012/10/20/04 38598 1/indeks. pendidikan.untuk.semua.masih. stagnan

Sardiman. 2009. Interaksi dan Motivasi Belajar Mengajar. Jakarta: PT Raja Grafindo Persada

Setianingrum, R. P. \& Titin Sunarti.

2013. Penerapan Model Pembelajaran Kooperatif Tipe NHT Dengan Media Physicround pada materi cahaya. Jurnal Inovasi Pendidikan Fisika

Sihotang. Ebtan. 2010. Pengaruh Model Pembelajaran

Kooperatif Tipe Numbered Heads Together (NHT) Terhadap Hasil Belajar Siswa pada Materi Pokok Hukum Newton di Kelas X Semester I SMA $N \quad 1$ Air Putih T.P 2009/2010. Medan: FMIPA UNIMED

Sudijono. A. 2009. Pengantar 
Evaluasi Pendikan. Jakarta:

Rajawali Pers

Sudjana. 2002. Metode Statistika.

Bandung: Tarsito

Sudjana. N. 2009. Penilaian Hasil

Belajar Mengajar. Bandung:

Remaja Rosdayakarya

Sukmadinata. N. S. 2003. Landasan

Psikologi Proses Pendidikan.

Bandung: Remaja

Rosdakarya

Trianto. 2009. Mendesain Model

Pembelajaran Inovatif-

Progesif. Jakarta: Prenada

Media

Yamin. M. 2004. Pengembangan

Kompetensi Pebelajar. Jakarta:

UI Pers 